\title{
A pesticide paradox: Fungicides indirectly increase fungal infections
}

\author{
Jason R. Rohr ${ }^{a, f}$, Jenise Brown ${ }^{a, b}$, William A. Battaglin ${ }^{c}$, Taegan A. McMahon ${ }^{d}$, and Rick A. \\ Relyea ${ }^{\mathrm{e}}$ \\ aUniversity of South Florida, Department of Integrative Biology, Tampa, FL 33620, USA \\ bSWCA Environmental Consultants, Pittsburgh, PA, 15017, USA \\ 'US Geological Survey, Colorado Water Science Center, Lakewood, CO, USA \\ dUniversity of Tampa, Department of Biology, Tampa, FL 33606, USA \\ eDepartment of Biological Sciences, Rensselaer Polytechnic Inst., Troy, NY 12180, USA
}

\section{Abstract}

There are many examples where the use of chemicals have had profound unintended consequences, such as fertilizers reducing crop yields (paradox of enrichment) and insecticides increasing insect pests (by reducing natural biocontrol). Recently, the application of agrochemicals, such as agricultural disinfectants and fungicides, has been explored as an approach to curb the pathogenic fungus, Batrachochytrium dendrobatidis $(B d)$, which is associated with worldwide amphibian declines. However, the long-term, net effects of early-life exposure to these chemicals on amphibian disease risk have not been thoroughly investigated. Using a combination of laboratory experiments and analysis of data from the literature, we explored the effects of fungicide exposure on $B d$ infections in two frog species. Extremely low concentrations of the fungicides azoxystrobin, chlorothalonil, and mancozeb were directly toxic to $B d$ in culture. However, estimated environmental concentrations of the fungicides did not reduce $B d$ on Cuban tree frog (Osteopilus septentrionalis) tadpoles exposed simultaneously to any of these fungicides and $B d$, and fungicide exposure actually increased $B d$-induced mortality. Additionally, exposure to any of these fungicides as tadpoles resulted in higher $B d$ abundance and greater $B d$-induced mortality when challenged with $B d$ post-metamorphosis, an average of 71 days after their last fungicide exposure. Analysis of data from the literature revealed that previous exposure to the fungicide itraconazole, which is commonly used to clear $B d$ infections, made the critically endangered booroolong frog (Litoria booroolongensis) more susceptible to $B d$. Finally, a field survey revealed that $B d$ prevalence was positively associated with concentrations of fungicides in ponds. Although fungicides show promise for controlling $B d$, these results suggest that, if fungicides do not completely eliminate $B d$ or if $B d$ re-colonizes, exposure to fungicides has the

\footnotetext{
‘corresponding author, jasonrohr@gmail.com.

Supporting Information

Additional supporting information may be found in the online version of this article at http://onlinelibrary.wiley.com/doi/10.1002/ eap.xxxx/suppinfo

Data Availability

Data available from Figshare: https://doi.org/10.6084/m9.figshare.5197378.v1
} 
potential to do more harm than good. To ensure that fungicide applications have the intended consequence of curbing amphibian declines, researchers must identify which fungicides do not compromise the pathogen resistance mechanisms of amphibians.

\section{Keywords}

Batrachochytrium salamandrivorans; agrochemicals; pesticides; biocontrol; parasite; chytrid fungus

\section{Introduction}

Synthetic chemicals have had enormous value to society, such as by treating and curing diseases and revolutionizing agricultural production. However, they can also have unanticipated consequences (Pimentel et al. 1973). In fact, there are several examples where applications of chemicals to the environment have had exactly the opposite effects than were intended. For example, the application of fertilizers can destabilize crop herbivore dynamics resulting in larger herbivore outbreaks that, in some years, can result in zero crop yields, a phenomenon called the paradox of enrichment (Rosenzweig 1971). The overuse of antibiotics in intensified livestock operations and medicine has resulted in antimicrobial resistance and perhaps an even more challenging public health crisis to manage (Young et al. 2016). Similarly, the application of insecticides has, in some cases, actually increased pests by having more adverse effects on arthropod predators of the pests than on the pests themselves, thus adversely affecting natural biocontrol (Desneux et al. 2007, Douglas et al. 2015). Additionally, there are numerous examples where chemicals can have substantial non-target effects that can disrupt rather than enhance ecosystem functions and services (McMahon et al. 2012, Halstead et al. 2014, Staley et al. 2014). These examples highlight the need to comprehensively understand the complex effects that chemicals can have on ecosystems to avoid inadvertent and undesirable ramifications.

Recently, several researchers have explored the effects of pesticides on the chytrid fungus, Batrachochytrium dendrobatidis $(B d)$, a pathogen associated with worldwide amphibian declines (Kilpatrick et al. 2010). For example, studies have explored how $B d$ is affected by herbicides (Gahl et al. 2011, McMahon et al. 2013, Rohr et al. 2013, Buck et al. 2015, Jones et al. 2016), insecticides (Davidson et al. 2007, Gaietto et al. 2014, Buck et al. 2015, Jones et al. 2016), fungicides (Johnson et al. 2003, Woodhams et al. 2012, McMahon et al. 2013, Gaietto et al. 2014, Hudson et al. 2016), and agricultural disinfectants (Johnson et al. 2003, Bosch et al. 2015). Additionally, many researchers are exploring biocides as management tools to control $B d$ (Woodhams et al. 2011). For example, Hanlon et al. (Hanlon et al. 2012) showed that the common agricultural fungicide thiophanate-methyl cleared frogs of $B d$ and had positive effects on their health, and Woodhams et al. (Woodhams et al. 2011) highlighted several studies where fungicides and disinfectants were being explored as management tools. More specifically, Bosch et al. (2015) successfully eradicated $B d$ from a field site using a fungicide and an agricultural disinfectant, and Hudson et al. (2016) temporarily reduced fungal loads on amphibians in the wild using in situ exposure to a fungicide. Thus, chemicals, such as fungicides and disinfectants with fungicidal properties, 
show exciting promise for managing amphibian chytridiomycosis. However, the long-term, net effects of early-life exposure to these chemicals on amphibian disease risk have not been thoroughly investigated.

In addition to intentional exposure to products with fungicidal properties to manage $B d$, amphibians are also regularly and unintentionally exposed to fungicides from direct overspray, drift, and run-off (Maltby et al. 2009, McMahon et al. 2011). Fungicides have experienced a greater increase in use in the last two decades than herbicides and insecticides. For example, in the US from 2004-2005, only $2 \%$ of all corn, soybean, and wheat fields were sprayed with fungicides, but this number increased to nearly 30\% by 2009 (Belden et al. 2010). The soybean industry estimates that 60 to $70 \%$ of soybean seed planted in 2014 had a fungicide seed treatment, compared to 30\% in 2008 and 8\% in 1996 (http:// unitedsoybean.org/article/six-things-farmers-should-know-about-seed-treatments/). Additionally, in the last 15 years in the US, an average of two new fungicides were registered for use each year, and in 2011 alone, the US Environmental Protection Agency reviewed the registration of 14 fungicides for 49 new uses, and all of the 14 fungicides are in use today (Battaglin et al. 2011).

Despite the widespread and increasing use of fungicides, there are few studies of the direct and indirect effects of fungicides on aquatic ecosystems (but see McMahon et al. 2011, McMahon et al. 2012) compared to the copious research on insecticides and herbicides (e.g. Relyea 2005, Rohr and Crumrine 2005, Rohr and McCoy 2010). For instance, a review of the indirect effects of pesticides on aquatic food webs found that only two out of the 150 research articles written from 1970-2002 addressed the use of a fungicide (Fleeger et al. 2003). Fungicides also are often very broad spectrum, affecting common and vital physiological processes, such as cellular respiration and immunity (Maltby et al. 2009). Additionally, modeling and monitoring suggest that fungicides might accumulate in freshwater habitats to levels above those considered safe for chronic exposure of some aquatic organisms (Deb et al. 2010).

The effects of pesticides on host-parasite interactions in particular can be extremely complex, having both positive and negative effects. As mentioned, several studies have shown that fungicides can be directly toxic to $B d$ (Hanlon and Parris 2012, McMahon et al. 2013). Chemical contaminants can also have negative effects on hosts by altering host immunity or parasite virulence (Relyea and Hoverman 2006, Rohr et al. 2006a, Jayawardena et al. 2016). Indeed, many pesticides are known to be immunomodulators (Voccia et al. 1999, Rohr et al. 2008b, Rohr and McCoy 2010, Rohr et al. 2015) and thus might have unfavorable effects on amphibian disease risk. Given the complexity of these direct and indirect effects, it is not surprising that studies exploring the effects of pesticides on $B d$ infections have produced mixed results (Davidson et al. 2007, Hanlon et al. 2012, McMahon et al. 2013, Buck et al. 2015, Hanlon et al. 2015, Jones et al. 2016).

Ultimately, what must be quantified is the sum of the positive and negative effects of contaminants to assess an overall or net effect (Rohr et al. 2008a). Additionally, net effects must be considered across life stages because exposure to chemicals early in life can have effects that persist into adulthood (e.g. Rohr and Palmer 2005, Rohr et al. 2006b). As an 
example, although the pesticide atrazine was directly toxic to $B d$ in culture (McMahon et al. 2013), the net effect of amphibian early-life exposure to this pesticide was an increase in $B d$ induced mortality because it had adverse effects on frog tolerance of infections that occurred later in life (Rohr et al. 2013).

Here, we use a combination of experiments and analysis of data from the literature to explore the net effects of exposure to four common fungicides on $B d$ infections in two frog species. To test for direct effects, we exposed $B d$ in culture to three commonly used fungicides each at five ecologically relevant concentrations. To test for indirect and persistent effects of fungicides, we conducted a laboratory experiment where tadpoles were exposed to these three fungicides or a control and challenged with $B d$ during the fungicide exposure period and/or after metamorphosis. To compare our results on these three fungicides used commonly in agriculture to itraconazole, the fungicide commonly used to clear amphibians of $B d$ (Garner et al. 2009, Berger et al. 2010), we analyzed data from the literature on the effects of itraconazole on susceptibility to $B d$. Finally, to evaluate the relevance of our results to natural settings, we tested whether fungicide levels in waterbodies and frog tissues were correlated with the prevalence of $B d$ infections.

We predicted that each fungicide would be directly toxic to $B d$. Given that most of these fungicides are documented to suppress immune responses of vertebrates (Colosio et al. 1996, Corsini et al. 2006, McMahon et al. 2011), we also expected that exposure to each fungicide would alter amphibian- $B d$ interactions (indirect effect). The direction of the net effect of fungicide exposure, however, was challenging to predict a priori. Additionally, we predicted that if any fungicide delayed metamorphosis, it would increase $B d$-loads on frogs by increasing the amount of time tadpoles were exposed to this predominantly aquatic fungus.

\section{Background on pathogen and fungicides}

$B d$ is a pathogenic chytrid fungus that causes chytridiomycosis in many amphibians. It is a major contributor to global amphibian declines and has been found on six continents (Kilpatrick et al. 2010). $B d$ infects amphibians by colonizing keratin-containing body regions, infecting the mouthparts of anuran tadpoles and later spreading to the skin as the skin becomes keratinized during metamorphosis (McMahon and Rohr 2015). Infection does not usually cause tadpole mortality, but post-metamorphic anurans can be extremely susceptible to $B d$ (McMahon et al. 2013, Gervasi et al. 2017) because the infection disrupts osmotic and electrolyte balance that is controlled by their skin, which can eventually lead to cardiac arrest (Voyles et al. 2009). Cellular immunity is an important defense against $B d$ and despite $B d$ being immunosuppressive, amphibians can acquire immunological resistance to $B d$ that overcomes this immunosuppression (McMahon et al. 2014).

Four fungicides were studied here: azoxystrobin, chlorothalonil, mancozeb, and itraconazole. The first three fungicides rank among the top five in the United States based on usage (Grube et al. 2011). Azoxystrobin has experienced a recent increase in usage in the US in the last couple of decades to combat the emergence of soybean rust and is also used commonly on grain crops (Battaglin et al. 2011). Chlorothalonil is used on a wide variety of 
crop species, as well as residential and golf course turf (Caux et al. 1996), and is the fungicide most commonly used in Latin America, a place where $B d$ effects on amphibians have been severe (Ghose et al. 2014). Mancozeb is primarily applied to potatoes to reduce fungal pathogens and is also sprayed on other food crops (Maltby et al. 2009, Grube et al. 2011). Azoxystrobin and chlorothalonil inhibit cellular respiration, and mancozeb disrupts lipid metabolism (Caux et al. 1996, Maltby et al. 2009, Battaglin et al. 2011), and thus all three chemicals have modes of action that affect vital physiological processes of many organisms, from bacteria to vertebrate animals. The half-lives and estimated peak environmental concentrations (based on US EPA EXAMS-PRZM software) of azoxystrobin, chlorothalonil, and mancozeb are 11-17 d, 1 to $48 \mathrm{~h}$, and 1-2 d and $\sim 2 \mathrm{ppb}, \sim 164 \mathrm{ppb}$, and $\sim 58 \mathrm{ppb}$, respectively.

Itraconazole is not heavily used in agriculture but is used in the medical and veterinary fields and is probably the most commonly used fungicide to clear $B d$ infections of amphibians (KuKanich 2008, Garner et al. 2009, Berger et al. 2010). Its mode of action is to inhibit fungal-mediated synthesis of ergosterol, and it can also inhibit cytochrome P450, which is important in metabolizing potentially toxic compounds (KuKanich 2008).

\section{Materials and Methods \\ Preparation of $\boldsymbol{B d}$ inoculum}

$B d$ inoculum was prepared by adding $1 \mathrm{~mL}$ of $B d$ stock (isolate SRS 812 isolated from a Rana catesbeiana in 2006 captured near the Savannah River Ecology Lab, SC, USA, passed through culture $\sim 12$ times) cultured in $1 \%$ tryptone broth, to a $1 \%$ tryptone agar plate. The plates were maintained at $23^{\circ} \mathrm{C}$ (estimate optimal temperature for growth for this culture) for approximately 1 week to allow $B d$ proliferation. Plates were inspected microscopically to verify that the zoospores were viable (swimming) and then they were then flooded with ultrapure water to suspend the zoospores. Water from the multiple agar plates was homogenized to create the $B d$ positive ( $B d+$ ) solutions. Zoospore density was standardized among replicates and concentrations above the target concentration were diluted with ultrapure water. The $B d$ negative ( $B d-$ ) solution was created using the same method, except that no $B d$ was added to the $1 \%$ tryptone agar plates.

\section{Effects of fungicides on Bd in culture}

To test for direct effects of the fungicides on $B d$ in culture, we used methods developed by McMahon et al. (2013). In a sterile, laminar flow hood, 10-mL glass test tubes were filled with $B d+$ solution (total concentration: $3.8 \times 10^{4}$ zoospores $/ \mathrm{mL}$ ), $1 \%$ tryptone broth, and one of four fungicide stocks $(0.001 \times, 0.01 \times, 0.1 \times, 1.0 \times$, and 10×estimate environmental concentration $[\mathrm{EEC}]$ or less for each of the three fungicides) or two control treatments (water and acetone solvent controls). Each treatment (concentration of each fungicide) was replicated 5 times for a total of 25 experimental units per fungicide, plus 10 control replicates. Test tubes were maintained at $23^{\circ} \mathrm{C}$ for $10 \mathrm{~d}$ after which $B d$ quantities were quantified by counting a $10-\mu \mathrm{L}$ aliquot of $B d$ with a hemocytometer. 


\section{Effects of fungicides on Bd growth on frogs in the laboratory}

The objectives of this experiment were to test for (1) the direct effects of fungicides on amphibians, (2) indirect effects of fungicides mediated by $B d$, and (3) persistent effects of fungicide exposure on amphibian susceptibility to $B d$. To accomplish these objectives, we collected Cuban tree frog tadpoles (Osteopilus septentrionalis) from a pond near the University of South Florida Botanical Gardens during the month of September 2012. We chose this frog species because it is common locally but is susceptible to chytrid infections (Rohr et al. 2013). In summary, we conducted a $4 \times 2 \times 2$ study with exposure to one of four fungicide treatments during larval development (azoxystrobin, chlorothalonil, mancozeb, solvent control) crossed with $B d$ exposure or not during larval development crossed with $B d$ exposure or not after metamorphosis (see below; Table S1, Fig. S1).

Each individual tadpole was weighed and staged (Gosner 1960) before the start of the experiment; stages and weights were equally distributed across all treatments. Individual tadpoles were exposed to treatments in a 500-mL glass jar filled with $300 \mathrm{~mL}$ of artificial spring water (ASW, Cohen et al. 1980). Throughout the experiment, animals were fed fish flakes and Sera Micron ad libitum.

The four fungicide treatments were an acetone control or the EEC of azoxystrobin (2.06 $\mu \mathrm{g} / \mathrm{L}$ ), chlorothalonil ( $164 \mu \mathrm{g} / \mathrm{L}$, we used the concentration of $30.0 \mu \mathrm{g} / \mathrm{L}$ because $164 \mu \mathrm{g} / \mathrm{L}$ will kill most of the frogs; McMahon et al. 2011, 2012), or mancozeb $(57.6 \mu \mathrm{g} / \mathrm{L})$. The treatments were applied to the water in each jar at the start of the experiment. These treatments were re-applied with every water change, which occurred weekly until metamorphosis or up to 12 weeks.

The $B d$ exposures occurred during the tadpole stage (simultaneous exposure with the fungicide treatments), after metamorphosis (delayed exposure; after fungicide treatments), both during the tadpole stage and after metamorphosis (double exposure; during and after fungicide treatments), or not at all (sham-exposed during both life stages). For the tadpole exposures, a 1-mL $B d$ inoculum $\left(2.88 \times 10^{6}-4.25 \times 10^{6}\right.$ zoospores $\left./ \mathrm{mL}\right)$ was added to the appropriate jar during weeks 1 and 3 of the experiment. All animals that were randomly assigned not to receive $B d$ during a given exposure period received a sham $B d$ exposure (see Preparation of Bd stocks).

The tadpoles were checked daily for metamorphosis or mortality. All animals that metamorphosed were swabbed (snout to vent and down each leg 5 times each), weighed, and maintained individually in 1-L plastic deli cups at $23^{\circ} \mathrm{C}$. Each post-metamorphic juvenile frog received vitamin- and mineral-dusted crickets ad libitum and weekly changes of wet papers towel. All animals that died were swabbed, weighed, and preserved. After 12 weeks, any tadpoles that had not metamorphosed were swabbed (mouthparts only; see McMahon and Rohr 2015) and euthanized using 0.5\% MS-222. Animals were then weighed, staged, and snout-vent length (SVL) was measured. The mouthparts were removed and stored in 95\% ethanol to later measure $B d$ loads.

At week 22, all metamorphic frogs were exposed to either $1 \mathrm{~mL}$ of $B d+$ inoculum $\left(1.69 \times 10^{6}\right.$ zoospores $/ \mathrm{mL}$ ) or $1 \mathrm{~mL}$ of the $B d$ - inoculum. For animals that were exposed only to a 
fungicide or control treatment as tadpoles, this was their first exposure to $B d$; for the simultaneous $B d$-fungicide treatment animals, this was the second $B d$ exposure. Five weeks after post-metamorphic exposure to $B d$ or the sham inoculum, the right hind limb (15 times hip to toe) of all frogs were swabbed. To optimize $B d$ growth, all frogs were moved to $17^{\circ} \mathrm{C}$ at week 32; all frogs were swabbed (15 times hip to toe) and then euthanized during week 38 (Fig. 2b).

Both swabs and tissues from the mouthparts of tadpoles provided DNA to quantify $B d$ abundance. $B d$ DNA was amplified through qPCR to calculate $B d$ infection abundance. All qPCR was performed according to Hyatt et al. (2007), using StepOne ${ }^{\mathrm{TM}}$ Real-Time PCR System (qPCRStepOne ${ }^{\mathrm{TM}}$ ).

We initially had 10 replicate frogs for each of these 16 treatments (160 frogs total). However, if a frog was assigned to receive a $B d$ exposure after metamorphosis and it died before this exposure, the animal was re-assigned to the appropriate treatment. For example, if a frog was assigned to receive $B d$ exposure both before and after metamorphosis but died before receiving the second $B d$ exposure after metamorphosis, it was shifted from the double $B d$ exposure treatment to the $B d$ before metamorphosis-only treatment. Likewise, if a frog was assigned to only receive $B d$ after metamorphosis and it died before receiving this treatment, it was reassigned to the no $B d$ before or after metamorphosis treatments. Hence, this had the effect of increasing sample sizes in some groups while decreasing the sample size in others. Sample sizes ended up as follows: simultaneous exposure $n=53$; delayed exposure $n=35$; double exposure $n=25$; sham-exposure $n=42$.

\section{Effects of the fungicide itraconazole on Bd growth on frogs in the laboratory}

Itraconazole is probably the most commonly used fungicide to clear frogs of $B d$ because of the existence of established amphibian application protocols (Garner et al. 2009, Berger et al. 2010) and thus is extremely relevant to the amphibian- $B d$ system. To evaluate whether itraconazole had similar effects as azoxystrobin, chlorothalonil, and mancozeb and to provide a test of the effects of fungicides on $B d$ infections by a completely independent laboratory (adding to the weight of evidence), we searched the literature for studies that exposed amphibians to itraconazole and then challenged them with $B d$. Cashins et al. (2013) conducted a study on the critically endangered booroolong frogs (Litoria booroolongensis) that satisfied this search criteria. However, they did not test for the effects of itraconazole on $B d$ prevalence in their study (see Data analysis for analyses).

\section{Effects of the fungicides on Bd prevalence in the field}

To investigate for an association between fungicide exposure and $B d$ infections, we collected water, bed sediment, $B d$, and frog tissue samples concurrently from 21 sites in seven states (CA, CO, GA, ID, LA, ME, and OR) in 2009 and 2010 and quantified $B d$ and fungicide concentrations. Details on the site locations, characteristics, and sampling design are provided in detail in Battaglin et al. (2016) and Smalling et al. (2015) and thus are only briefly covered here. Approximately $1 \mathrm{~L}$ of water and a stainless steel scoop of bed sediment were collected from each site to quantify pesticide or pesticide degradates. One to 15 adult frogs were collected at each site (see Results for details on frogs species collected) by hand 
or net and swabbed for $B d$ (Hyatt et al. 2007). The frogs were euthanized, wrapped in aluminum foil, and then placed in a freezer for later whole-body analysis of pesticides and pesticide degradates (Battaglin et al. 2016).

Filtered water samples were analyzed for a suite of pesticides and pesticide degradates by extracting onto a solid phase extraction cartridge, spiking the samples with a recovery surrogate, eluting the cartridge with ethyl acetate, adding a deuterated internal standard, and analyzing the extracts on an Agilent (Santa Clara, CA) 7890 gas chromatograph coupled to an Agilent 5975 (Folsom, CA) mass spectrometer. Data for all pesticides were collected in selective ion monitoring mode with each compound having one quantifier ion and one to two qualifier ions. Wet sediments ( $10 \mathrm{~g}$ ) were analyzed similarly to the water samples with the following exceptions. The sediment was homogenized with sodium sulfate, extracted using pressurized liquid extraction, dried over sodium sulfate, reduced, and sulfur was removed by gel permeation chromatography. Samples were subjected to a clean-up method with $6 \%$ deactivated Florisil. Frog tissue samples were analyzed similarly to the water samples with the following exceptions. Individual whole frogs (3-5 g) were thawed, homogenized with sodium sulfate $\left(\mathrm{Na}_{2} \mathrm{SO}_{4}\right)$ using a mortar and pestle, extracted three times with dichloromethane using pressurized liquid extraction, dried over $\mathrm{Na}_{2} \mathrm{SO}_{4}$, and reduced to 1 $\mathrm{mL}$. Ten percent by volume of each raw extract was allowed to evaporate to a constant weight in a fume hood for gravimetric lipid determination to the nearest $0.001 \mathrm{~g}$ using a microbalance. A majority of the lipid was removed using gel permeation chromatography followed by $6 \%$ deactivated Florisil previously activated at $550{ }^{\circ} \mathrm{C}$ for $16 \mathrm{~h}$ (Battaglin et al. 2016).

\section{Data analysis}

All statistical analyses were conducted using R statistical software. For the study that examined $B d$ responses to three fungicides, we conducted analyses on each of the three fungicides separately. We tested for a relationship between fungicide concentration and $B d$ abundance (rounded zoospore equivalents) using a negative binomial distribution (function: glmmadmb, package: glmmadmb). We tested for differences among the concentrations using a sequential Bonferroni adjustment.

For the laboratory study on frogs, we used a generalized linear model with a binomial error distribution to determine whether the fungicide treatments, $B d$ treatments, and their interaction significantly affected whether a frog lived or died during the experiment, and used a factorial ANOVA to evaluate how treatments affected log mass at and time to metamorphosis. Additionally, we conducted two analyses on $B d$ abundance. First, we compared the loads of frogs exposed to $B d$ for the first time across fungicide treatments to see if simultaneous exposure to $B d$ and fungicides resulted in different fungal loads than early-life exposure to fungicides and later-life exposure to $B d$. For frogs exposed simultaneously to $B d$ and fungicide treatments, the response variable was $B d$ load at metamorphosis or $B d$ load at death if they did not reach metamorphosis. For frogs exposed to $B d$ after they were exposed to fungicide treatments (i.e. after metamorphosis), we used the mid-survey (experimental day 155) $B d$ load or $B d$ load at death if they did not reach the mid-survey swabbing. Second, we compared the $B d$ load of post-metamorphic frogs 
receiving their first and second exposures to $B d$ using the mid-survey swabs. In all analyses treating $B d$ abundance on the frogs as a response, we included fungicide treatments, timing of $B d$ exposures, their interaction, and initial mass (unless it was not significant) as fixed effects. We analyzed $B d$ abundance using a zero-inflated negative binomial model (it was a better fit [AIC=1009] than the negative binomial model [AIC=1038]; function: zeroinfl, package: pscl).

To test whether the fungicide itraconazole was immunosuppressive to booroolong frogs in the Cashins et al. (2013) study, we applied a Chi square analysis to their data to compare $B d$ prevalence of frogs previously exposed to itraconazole or not.

Finally, to evaluate how fungicides affected $B d$ infections in the field, we used multiple regression with a binomial error distribution (function: glm, package stats) to test how the concentration of fungicides in frog tissues, sediment, and water affected $B d$ prevalence and quantify the fit of this model using the Nagelkerke Index (Nagelkerke 1991). We did not analyze $B d$ abundance data because we did not know the time course of infection for each frog, and thus we conservatively focused on prevalence. However, we did evaluate whether any differences among frog species in their fungicides or $B d$ loads could account for any detected patterns between fungicides and $B d$ prevalence. All $p$-values were calculated using log-likelihood ratio tests (function: Anova, package: car).

\section{Results}

\section{Effects of fungicides on $B d$ in culture}

Relative to the acetone control, all tested concentrations of azoxystrobin and chlorothalonil (Concentration: $X^{2}=19.96, p<0.001$ and $X^{2}=15.22, p<0.001$, respectively; Table 1) and all tested concentrations of mancozeb except the lowest concentration (Concentration: $X^{2}=6.81$, $p=0.009$; Table 1) significantly reduced $B d$ abundance in culture relative to the controls.

\section{Effects of fungicides on Bd growth on frogs in the laboratory}

There were no significant effects of the fungicides, $B d$ treatments, or their interactions on time to metamorphosis or mass at metamorphosis (Tables $\mathrm{S} 1 \& \mathrm{~S} 2$ ). For the $B d$ analyses, we first tested for an effect of fungicide treatments on $B d$ abundance on frogs that were exposed to $B d$ for the first time, which included frogs exposed to $B d$ and the fungicide treatments simultaneously and frogs exposed to fungicide treatments as tadpoles but to $B d$ an average of 71 days after metamorphosis. In these analyses, frogs were not all swabbed at the same time because they metamorphosed or died at different times. Duration of time that $B d$ grew on the frogs was never a significant predictor in the models $\left(X^{2}=2.97, p>0.225\right)$. However, whether a frog was swabbed at death was always a significant predictor $(p<0.05)$ because frogs that died from infection had, on average, more $B d$ than frogs swabbed while alive. Therefore, we included whether a frog was swabbed at death as a categorical factor rather than time for $B d$ growth in each model. Initial mass was included in most models because it was generally a negative predictor of $B d$ intensity.

In these analyses, mean $B d$ abundance on frogs never differed significantly among the three fungicide treatments, regardless of whether $B d$ exposure occurred simultaneous with the 
fungicide exposure $\left(X^{2}=2.65, p=0.618\right)$ or later in life $\left(X^{2}=0.61, p=0.961\right.$; Table S3). In addition, exposure to any of the three fungicides resulted in significantly more $B d$ on frogs compared to frogs exposed to the solvent control (Fungicide main effect: $p<0.05$; Table S3). Hence, we pooled the fungicides together for ease of interpretation and to increase statistical power. There was no significant effect of the fungicides on $B d$ abundance when the fungicide and $B d$ exposures occurred simultaneously as tadpoles (Fig. 1A); however, when the $B d$ exposure occurred after metamorphosis, an average of 71 days since the previous exposure to fungicides, the previous fungicide exposure caused a nearly 3.5-fold increase $B d$ abundance on frogs relative to the solvent controls (Fungicidextiming of $B d$ exposure: $X^{2}=25.98, p<0.001$; Fig. 1 A).

We also compared the $B d$ load of post-metamorphic frogs receiving their first and second exposures to $B d$. These analyses revealed a significant two-way interaction between the fungicide treatment and number of $B d$ exposures $\left(X^{2}=15.47, p<0.001\right)$. Frogs exposed to fungicide and $B d$ for the first time had higher $B d$ loads than frogs exposed to solvent and $B d$ for the first time ( $X^{2}=12.85, p=0.002$; Fig. 1B, Table S4). However, the opposite trend occurred on the second exposure. Frogs exposed to fungicide and $B d$ for the second time had lower $B d$ loads than frogs exposed to the solvent and $B d$ for the second time, although not significantly so because of low sample size and high variability in the control $\left(X^{2}=2.95\right.$, $p=0.229$; Fig. 1B, Table S4).

For the analyses on survival, we conducted binomial survival analyses that assessed how treatments affected the probabilities of surviving the length of the experiment. In these analyses, mean mortality of frogs exposed to the three fungicides never differed, regardless of whether $B d$ exposure occurred simultaneous with the fungicide exposure $\left(X^{2}=1.33\right.$, $p=0.515)$, later in life (delayed) $\left(X^{2}=0.23, p=0.892\right)$, or both (double exposure; $X^{2}=2.35$, $p=0.309$ ). However, for the simultaneous and delayed exposure treatments, each fungicide caused significantly greater mortality than the solvent control $(p<0.04)$. Hence, we again pooled the fungicides for ease of interpretation and to increase statistical power.

We compared $B d$-induced mortality in the fungicide versus control treatments for frogs exposed to $B d$ for the first time. Despite not having significantly more $B d$ than controls, tadpoles exposed simultaneously to fungicide and $B d$ had greater mortality than tadpoles exposed to solvent, fungicides alone, and $B d$ alone, resulting in a significant interaction between fungicide and $B d$ treatments (Fungicide* $B d: X^{2}=6.47, p=0.011$; Fig. 2A). A similar but more pronounced pattern was observed when the $B d$ exposure occurred after metamorphosis, there was significantly greater $B d$-induced mortality if frogs were previously exposed to fungicide than solvent control (Fungicide* $B d: X^{2}=6.28, p=0.012$; Fig. 2B).

We also compared the $B d$-induced mortality of post-metamorphic frogs receiving their first and second exposures to $B d$. If metamorphs were exposed to $B d$ for the first time, there was greater $B d$-induced mortality among frogs previously exposed to fungicide than solvent control ( $X^{2}=6.28, p=0.012$, Fig. $\left.2 \mathrm{~B}\right)$. However, similar to our $B d$ abundance results, the opposite trend was observed when metamorphs were exposed to $B d$ for the second time; there was greater $B d$-induced mortality among frogs previously exposed to solvent control 
than fungicides, although not significantly so $\left(X^{2}=1.51, p=0.220\right.$; Fig. $\left.2 \mathrm{~B}\right)$. This resulted in a significant interaction between fungicide treatment and number of $B d$ exposures $\left(X^{2}=6.90\right.$, $p=0.009$ ) because there was a significant effect during the first exposure and not during the second exposure.

\section{Effects of the fungicide itraconazole on Bd growth on frogs in the laboratory}

Booroolong frogs previously exposed to itraconazole in the Cashins et al. (2013) study had significantly higher $B d$ prevalence when exposed to $B d$ later in life $(91 \%, 10 / 11$ frogs) than frogs not previously exposed to itraconazole ( $50 \%, 14 / 28$ frogs; $\left.X^{2}=5.58, p=0.018\right)$.

\section{Effects of the fungicides on Bd growth on frogs in the field}

Twelve different fungicides were detected in the 21 wetlands that were sampled (Table S5). The three most common fungicides detected in sediment were pyraclostrobin $(52 \%)$, chlorothalonil (33\%), and tebuconazole (24\%), and the only fungicide detected from water samples at multiple sites was azoxystrobin (19\%, Table S5). Given the infrequency in which individual fungicides were detected, we combined fungicide concentrations for the analyses.

A total of 138 frogs were swabbed for $B d$ and also had fungicides quantified from their tissues. Of these frogs, 54 were positive for $B d$ and 72 had quantifiable levels of fungicides in their tissues. Only four wetlands had detectable levels of fungicides in the water column, whereas all but three had detectable levels in sediment (Table S5). Given how few wetlands had detectable fungicide in the water column, we chose to simply add the water column and sediment concentrations to reflect overall environmental exposure, but admit that much of this exposure appears to be through sediment. $B d$ prevalence on frogs was not significantly related to the concentration of fungicides in frog tissues $\left(X^{2}=0.03, p=0.858\right.$, Nagelkerke Index $=0.001$, Fig. $3 \mathrm{~A}$ ), but was positively related to the concentration of fungicides (sediment plus water) in waterbodies $\left(X^{2}=7.10, p=0.008\right.$, Nagelkerke Index $=0.069$, Fig. 3B). Two genera of frogs were captured, Pseudacris (65\%) and Rana (35\%; Fig. S2). Five species were captured but $65 \%$ were just two species, Pseudacris regilla and $P$. triseriata (Fig. S2). Loads of $B d$ were higher for genus Pseudacris than Rana, but Pseudacris was less likely to be found at sites with high concentrations of fungicides (Fig. S2). Thus, differences in $B d$ loads across genera do not seem capable of accounting for the detected positive relationship between fungicides and $B d$ (Fig. 3).

\section{Discussion}

When tadpoles were exposed to both a fungicide and $B d$ simultaneously in the laboratory, none of the three fungicides affected $B d$ loads on the frogs compared to the no-fungicide control. In contrast, frogs exposed to $B d$ as metamorphs, an average of 71 days since any fungicide exposure, had significantly greater $B d$ abundance and greater $B d$-induced mortality than frogs exposed to the solvent control. The type of applied fungicide did not matter with all samples exhibiting the same reaction to the three fungicides, azoxystrobin, chlorothalonil, and mancozeb. Research from a completely independent laboratory on the critically endangered booroolong frog found exactly the same results for itraconazole (Cashins et al. 2013), the most commonly used fungicide to clear frogs of $B d$ (Garner et al. 
2009, Berger et al. 2010). Booroolong frogs previously exposed to itraconazole had significantly greater $B d$ prevalence when challenged with $B d$ later in life than frogs not previously exposed to itraconazole. Hence, despite four commonly used fungicides being directly toxic to $B d$ (see Table 1), all paradoxically increased $B d$ infections by having persistent adverse effects on frog resistance to this fungal pathogen.

Interestingly, the increase in $B d$ abundance and $B d$-induced mortality associated with fungicide exposure in our laboratory study was greater if we exposed the frogs to $B d$ an average of 71 days after the fungicide exposure than if we exposed the frogs to $B d$ and fungicide simultaneously. This result is probably a product of two factors. First, the culture experiment demonstrated that all three tested fungicides are directly toxic to $B d$ and thus almost certainly reduced the abundance of $B d$ on frogs when the two occurred simultaneously. However, any direct toxicity to $B d$ was clearly not as strong as the adverse effect of the fungicides on the fungal defenses of the frogs. Second, $B d$ is believed to consume keratin, which is only found on the mouthparts of tadpoles but is throughout the skin of metamorphs (McMahon and Rohr 2015). Hence, $B d$ might also be able to proliferate more rapidly after metamorphosis, amplifying the effect of fungicide exposure more so after than before metamorphosis. Given that the fungicides did not affect timing of or size at metamorphosis, these traits seem unlikely to explain any observed effects.

The observed persistent effects of early-life exposure to fungicides on infectious disease risk are consistent with several previous toxicological studies. Several pesticides have been shown to cause changes in host-parasite dynamics (Relyea and Hoverman 2006, Rohr et al. 2006a, Rohr and McCoy 2010) and have delayed effects on host behavior, growth, physiology, and survival (e.g. Rohr and Palmer 2005, Rohr et al. 2006b, Jones et al. 2009, Rohr et al. 2013). Similar to our findings, other studies have shown that fungicides can be directly toxic to $B d$ (Hanlon and Parris 2012, McMahon et al. 2013). In contrast to our work, some of these previous studies revealed that fungicide exposures can actually reduce $B d$ growth rates on frogs, but these previous studies did not test for the effects of sequential fungicide and $B d$ exposures and did not test for persistent adverse effects of early-life exposure to fungicides (Hanlon et al. 2012, Hanlon and Parris 2012, McMahon et al. 2013, Hanlon et al. 2015).

There are several potential mechanisms by which early-life exposure to chemicals can have persistent effects on infectious disease risk. Pesticide exposure early in life can induce stress responses, elevating cortisol, corticosterone, or other stress-related hormones; chronic levels of these hormones have been associated with persistent immunomodulation (Martin et al. 2010, McMahon et al. 2011, McMahon et al. 2017). Chemical contaminants have also been shown to disrupt the microbiome of hosts. The gut microbiome has been linked to immune development in vertebrates (Hooper et al. 2012) and the skin microbiome in amphibians has been shown to inhibit the growth of $B d$ (Bletz et al. 2013). Two recent studies revealed that tadpole exposure to chemical contaminants reduced their gut and skin microbiota and reductions in gut microbiota were associated with reduced resistance to skin-penetrating gut nematodes and $B d$ later in life (Knutie et al. in review, Knutie et al. in press). Understanding the mechanisms by which pesticides cause long-term impacts on host defenses will be necessary to improve the design of pesticides. 
Interestingly, the pattern of higher $B d$ abundance in fungicide- than solvent-exposed frogs was not apparent upon a second exposure to $B d$. Frogs exposed to fungicides and to $B d$ for the second time had similar $B d$ loads as control frogs and had lower $B d$ loads than fungicide-exposed frogs exposed to $B d$ for the first time when exposed at the same life stage (Fig. 1B). This pattern was most likely caused by $B d$-induced mortality. Frogs exposed to fungicide and $B d$ for the first time had significantly higher mortality than frogs exposed to solvent and $B d$ for the first time. In fact, $B d$ only caused significant mortality when frogs were exposed to fungicides. Hence, the most $B d$-susceptible individuals were not available to be exposed to $B d$ for a second time in the fungicide treatments but were available for exposure to $B d$ a second time in the control treatment. Consequently, selection is a resonable explanation for the change in $B d$ abundance and mortality patterns across fungicide treatments between the first and second $B d$ exposures (Rohr et al. 2008a).

Despite the broad spectrum nature of many fungicides (Maltby et al. 2009), we did not detect strong direct effects of the tested fungicides on Cuban tree frogs in our laboratory experiments. The fungicides alone did not affect survival or timing of or size at metamorphosis. Rather, most of the adverse or beneficial effects of fungicides were only apparent in the presence of $B d$. The fungicides reduced $B d$ growth on frogs when the exposures occurred simultaneously. However, they tended to increase $B d$-induced mortality regardless of the timing of exposures. These findings emphasize the importance of considering the effects of contaminants within a community context (Relyea and Hoverman 2006, Rohr et al. 2006a), quantifying the net effects of contaminants (the sum of the beneficial and adverse effects) (Rohr et al. 2008a), and testing for delayed or persistent effects of chemicals (Rohr and Palmer 2005, Rohr et al. 2006b, Jones et al. 2009, Rohr and Palmer 2013).

The patterns we observed in nature were consistent with our laboratory findings because fungicides were generally associated with greater rather than less $B d$. In our field survey, we revealed that the greater the concentration of fungicides in a given wetland, the greater the prevalence of chytrid fungal infections in frogs (Fig. 3B). In contrast, fungicide concentrations at the level of individual frogs were less correlated with $B d$ prevalence (Fig. $3 \mathrm{~A}$ ), perhaps because of individual-level variation in susceptibility, exposure, and timing and duration of infections, variation that is reduced at the level of the wetland. In addition to reflecting current exposure, detectable levels of fungicides in wetlands must also reflect some level of previous fungicide exposure, which, according to our laboratory experiments, can persistently compromise host resistance to $B d$. Importantly, given that $B d$ can be quite persistent in the presence of abundant hosts and that many fungicides often degrade rapidly in the environment, exposure to fungicide followed by exposure to $B d$ is almost certainly more frequent than simultaneous exposure to the two factors, suggesting that persistent adverse effects of previous fungicide exposure might be common. Additionally, our field patterns revealed that fungicides were rarely detected in the water column but were regularly detected in sediments, suggesting that adsorption might be important for many fungicides and that benthos-dwelling tadpole species might have higher fungicide exposure than species found more commonly in other microhabitats. Additional field data and field manipulations would be invaluable in determining the absolute magnitude of these effects and the specific fungicides that are driving these patterns. 
Recently, there have been some exciting findings that suggest applications of fungicides or disinfectants with fungicidal properties might be an effective tool for curbing amphibian declines associated with $B d$ (Bosch et al. 2015, Hudson et al. 2016). Bosch et al. (2015) used fungicides and agricultural disinfectants to successfully eradicate $B d$ from a field site and Hudson et al. (2016) temporarily reduced fungal loads on amphibians in the wild using in situ exposure to fungicides. However, our results show that many fungicides can also have adverse effects, such as persistently compromising amphibian defenses against pathogens. Thus, fungicides might work well if they completely eliminate $B d$ from the environment and if $B d$ is unlikely to return soon after. However, if a fungicide application does not eradicate $B d$, if it does eradicate $B d$ but $B d$ re-colonizes, or if fungicide-induced suppression of host defenses affects resistance to other virulent pathogens in the environment (bacteria, viruses, macroparasites, protozoa, etc.), our results suggest that fungicide applications could cause more harm than good. Indeed, if fungicides and disinfectants do not clear both the frog and environment of $B d$, our results suggest that they can eventually elevate $B d$ prevalence.

Additionally, many broad spectrum pesticides have widespread non-target effects (Jones et al. 2009, Halstead et al. 2014), but the consequences of fungicide exposure on non-target organisms are not fully understood. Although fungicides show promise for controlling $B d$, the recently discovered chytrid of salamanders Batrachochytrium salamandrivorans (Martel et al. 2013), and perhaps even other emerging fungal diseases, such as those of bats, bees, corals, and snakes (Allender et al. 2011, Cameron et al. 2011, Warnecke et al. 2012), for all of the reasons just provided, we encourage greater research on and caution in using fungicides for managing infectious diseases of wildlife. In particular, research is needed to more concretely identify which fungicides can control fungal pathogens without compromising host resistance and tolerance of pathogens.

Although synthetic chemicals provide an enormous value to society, they also have had many unintended consequences (Pimentel et al. 1973). Examples include the paradox of enrichment, where fertilizers reduce crop yields (Rosenzweig 1971) and cases where insecticides cause greater pest outbreaks by reducing natural biocontrol (Desneux et al. 2007, Douglas et al. 2015). Here, we provided yet another example to this growing list. Fungicides paradoxically increased fungal loads and fungal-induced mortality of amphibians. These findings highlight the importance of understanding the role of multiple simultaneous and sequential stressors in biodiversity declines and disease emergences and the need to comprehensively understand the complex effects that chemicals can have on ecosystems to avoid inadvertent and undesirable ramifications.

\section{Supplementary Material}

Refer to Web version on PubMed Central for supplementary material.

\section{Acknowledgments}

We thank D. L. Calhoun, S. Paschke, and K. Smalling for feedback on this manuscript. This research was supported by grants from the National Science Foundation (EF-1241889), National Institutes of Health (R01GM109499, R01TW010286), US Department of Agriculture (NRI 2006-01370, 2009-35102-0543), and US Environmental Protection Agency (CAREER 83518801) to J.R.R., and The University of Tampa's Dana Faculty Development Grant to T.A.M. The field research was supported by the US Geological Survey's Amphibian Research and Monitoring Initiative. Any use of trade, firm, or product names is for descriptive purposes only and does not imply 
endorsement by the U.S. Government. W.A.B. did not materially contribute to the model application described in this publication. J.R.R. and J.B. are equal first authors.

\section{Literature Cited}

Allender MC, Dreslik M, Wylie S, Phillips C, Wylie DB, Maddox C, Delaney MA, Kinsel MJ. Chrysosporium sp. infection in eastern massasauga rattlesnakes. Emerging Infectious Diseases. 2011; 17:2383-2384. [PubMed: 22172594]

Battaglin W, Smalling K, Anderson C, Calhoun D, Chestnut T, Muths E. Potential interactions among disease, pesticides, water quality and adjacent land cover in amphibian habitats in the United States. Science of the Total Environment. 2016; 566:320-332. [PubMed: 27232962]

Battaglin WA, Sandstrom MW, Kuivila KM, Kolpin DW, Meyer MT. Occurrence of azoxystrobin, propiconazole, and selected other fungicides in US streams, 2005-2006. Water, Air, \& Soil Pollution. 2011; 218:307-322.

Belden J, McMurry S, Smith L, Reilley P. Acute toxicity of fungicide formulations to amphibians at environmentally relevant concentrations. Environmental Toxicology and Chemistry. 2010; 29:24772480. [PubMed: 20836054]

Berger L, Speare R, Pessier A, Voyles J, Skerratt LF. Treatment of chytridiomycosis requires urgent clinical trials. Diseases of Aquatic Organisms. 2010; 92:165-174. [PubMed: 21268978]

Bletz MC, Loudon AH, Becker MH, Bell SC, Woodhams DC, Minbiole KP, Harris RN. Mitigating amphibian chytridiomycosis with bioaugmentation: characteristics of effective probiotics and strategies for their selection and use. Ecology Letters. 2013; 16:807-820. [PubMed: 23452227]

Bosch J, Sanchez-Tome E, Fernandez-Loras A, Oliver JA, Fisher MC, Garner TWJ. Successful elimination of a lethal wildlife infectious disease in nature. Biology Letters. 2015; 11

Buck JC, Hua J, Brogan WR III, Dang TD, Urbina J, Bendis RJ, Stoler AB, Blaustein AR, Relyea RA. Effects of pesticide mixtures on host-pathogen dynamics of the amphibian chytrid fungus. PLoS One. 2015; 10

Cameron SA, Lozier JD, Strange JP, Koch JB, Cordes N, Solter LF, Griswold TL. Patterns of widespread decline in North American bumble bees. Proceedings of the National Academy of Sciences of the United States of America. 2011; 108:662-667. [PubMed: 21199943]

Cashins SD, Grogan LF, McFadden M, Hunter D, Harlow PS, Berger L, Skerratt LF. Prior infection does not improve survival against the amphibian disease chytridiomycosis. PLoS One. 2013; 8:e56747. [PubMed: 23451076]

Caux PY, Kent RA, Fan GT, Stephenson GL. Environmental fate and effects of chlorothalonil: a Canadian perspective. Critical Reviews in Environmental Science and Technology. 1996; 26:4593.

Cohen LM, Neimark H, Eveland LK. Schistomsoma mansoni: Response of cercariae to a thermal gradient. Journal of Parasitology. 1980; 66:362-364. [PubMed: 7391881]

Colosio C, Barcellini W, Maroni M, Alcini D, Bersani M, Cavallo D, Galli A, Meroni P, Pastorelli R, Rizzardi GP, Soleo L, Foa V. Immunomodulatory effects of occupational exposure to mancozeb. Archives of Environmental Health. 1996; 51:445-451. [PubMed: 9012323]

Corsini E, Viviani B, Birindelli S, Gilardi F, Torri A, Codeca I, Lucchi L, Bartesaghi S, Galli CL, Marinovich M, Colosio C. Molecular mechanisms underlying mancozeb-induced inhibition of TNF-alpha production. Toxicology and Applied Pharmacology. 2006; 212:89-98. [PubMed: 16112155]

Davidson C, Benard MF, Shaffer HB, Parker JM, O'Leary C, Conlon JM, Rollins-Smith LA. Effects of chytrid and carbaryl exposure on survival, growth, and skin peptide defenses in foothill yellowlegged frogs. Environmental Science \& Technology. 2007; 41:1771-1776. [PubMed: 17396672]

Deb D, Engel BA, Harbor J, Hahn L, Lim KJ, Zhai T. Investigating potential water quality impacts of fungicides used to combat soybean rust in Indiana. Water Air and Soil Pollution. 2010; 207:273288.

Desneux N, Decourtye A, Delpuech J-M. The sublethal effects of pesticides on beneficial arthropods. Pages 81-106 Annual Review of Entomology. 2007 
Douglas MR, Rohr JR, Tooker JF. Neonicotinoid insecticide travels through a soil food chain, disrupting biological control of non-target pests and decreasing soya bean yield. Journal of Applied Ecology. 2015; 52:250-260.

Fleeger JW, Carman KR, Nisbet RM. Indirect effects of contaminants in aquatic ecosystems. Science of the Total Environment. 2003; 317:207-233. [PubMed: 14630423]

Gahl MK, Pauli BD, Houlahan JE. Effects of chytrid fungus and a glyphosate-based herbicide on survival and growth of wood frogs (Lithobates sylvaticus). Ecological Applications. 2011; 21:2521-2529. [PubMed: 22073641]

Gaietto KM, Rumschlag SL, Boone MD. Effects of pesticide exposure and the amphibian chytrid fungus on gray treefrog (Hyla chrysoscelis) metamorphosis. Environmental Toxicology and Chemistry. 2014; 33:2358-2362. [PubMed: 25044296]

Garner TWJ, Garcia G, Carroll B, Fisher MC. Using itraconazole to clear Batrachochytrium dendrobatidis infection, and subsequent depigmentation of Alytes muletensis tadpoles. Diseases of Aquatic Organisms. 2009; 83:257-260. [PubMed: 19402457]

Gervasi SS, Stephens PR, Hua J, Searle CL, Xie G, Urbina J, Olson D, Bancroft BA, Weis V, Hammond JI, Relyea RA, Blaustein AR. Linking ecology and epidemiology to understand predictors of multi-host responses to an emerging pathogen, the amphibian chytrid fungus. PLoS One. 2017; 12:e0167882. doi:0167810.0161371/journal.pone.0167882. [PubMed: 28095428]

Ghose SL, Donnelly MA, Kerby J, Whitfield SM. Acute toxicity tests and meta-analysis identify gaps in tropical ecotoxicology for amphibians. Environmental Toxicology and Chemistry. 2014; 33:2114-2119. [PubMed: 24934557]

Gosner N. A simplified table for staging anuran embryos and larvae with notes on identification. Herpetologica. 1960; 16:183-190.

Grube, A., Donaldson, D., Kiely, T., Wu, L. Pesticide industry sales and usage: 2006 and 2007 market estimates. U.S. Environmental Protection Agency; Washington, D.C.: 2011.

Halstead NT, McMahon TA, Johnson SA, Raffel TR, Romansic JM, Crumrine PW, Rohr JR. Community ecology theory predicts the effects of agrochemical mixtures on aquatic biodiversity and ecosystem properties. Ecology Letters. 2014; 17:932-941. [PubMed: 24811760]

Hanlon SM, Kerby JL, Parris MJ. Unlikely remedy: Fungicide clears infection from pathogenic fungus in larval southern leopard frogs (Lithobates sphenocephalus). PLoS One. 2012; 7

Hanlon SM, Lynch KJ, Kerby JL, Parris MJ. The effects of a fungicide and chytrid fungus on anuran larvae in aquatic mesocosms. Environmental Science and Pollution Research. 2015; 22:1292912940. [PubMed: 25913318]

Hanlon SM, Parris MJ. The impact of pesticides on the pathogen Batrachochytrium dendrobatidis independent of potential hosts. Archives of Environmental Contamination and Toxicology. 2012; 63:137-143. [PubMed: 22228138]

Hooper LV, Littman DR, Macpherson AJ. Interactions between the microbiota and the immune system. Science. 2012; 336:1268-1273. [PubMed: 22674334]

Hudson MA, Young RP, Lopez J, Martin L, Fenton C, McCrea R, Griffiths RA, Adams S, Gray G, Garcia G, Cunningham AA. In-situ itraconazole treatment improves survival rate during an amphibian chytridiomycosis epidemic. Biological Conservation. 2016; 195:37-45.

Hyatt AD, Boyle DG, Olsen V, Boyle DB, Berger L, Obendorf D, Dalton A, Kriger K, Hero M, Hines H, Phillott R, Campbell R, Marantelli G, Gleason F, Colling A. Diagnostic assays and sampling protocols for the detection of Batrachochytrium dendrobatidis. Diseases of Aquatic Organisms. 2007; 73:175-192. [PubMed: 17330737]

Jayawardena UA, Rohr JR, Navaratne AN, Amerasinghe PH, Rajakaruna RS. Combined effects of pesticides and trematode infections on hourglass tree frog Polypedates cruciger. EcoHealth. 2016; 13:111-122. [PubMed: 26911919]

Johnson ML, Berger L, Philips L, Speare R. Fungicidal effects of chemical disinfectants, UV light, desiccation and heat on the amphibian chytrid Batrachochytrium dendrobatidis. Diseases of Aquatic Organisms. 2003; 57:255-260. [PubMed: 14960039]

Jones DK, Dang TD, Urbina J, Bendis RJ, Buck JC, Cothran RD, Blaustein AR, Relyea RA. Effect of simultaneous amphibian exposure to pesticides and an emerging fungal pathogen, Batrachochytrium dendrobatidis. Environmental Science \& Technology. 2016 
Jones DK, Hammond JI, Relyea RA. Very highly toxic effects of endosulfan across nine species of tadpoles: Lag effects and family-level sensitivity. Environmental Toxicology and Chemistry. 2009; 28:1939-1945. [PubMed: 19358624]

Kilpatrick AM, Briggs CJ, Daszak P. The ecology and impact of chytridiomycosis: an emerging disease of amphibians. Trends in Ecology \& Evolution. 2010; 25:109-118. [PubMed: 19836101]

Knutie SA, Gabor CR, Kohl KD, Rohr JR. Do host-associated gut microbiota mediate the effect of an herbicide on disease risk in frogs? Journal of Animal Ecology. in review.

Knutie SA, Wilkinson CL, Kohl KD, Rohr JR. Early-life disruption of host microbiota decreases laterlife resistance to infections. Nature Communications. in press.

Kukanich B. A review of selected systemic antifungal drugs for use in dogs and cats. Veterinary Medicine. 2008; 103:41-50.

Maltby L, Brock TCM, van den Brink PJ. Fungicide risk assessment for aquatic ecosystems: Importance of interspecific variation, toxic mode of action, and exposure regime. Environmental Science \& Technology. 2009; 43:7556-7563. [PubMed: 19848176]

Martel A, Spitzen-van der Sluijs A, Blooi M, Bert W, Ducatelle R, Fisher MC, Woeltjes A, Bosman W, Chiers K, Bossuyt F. Batrachochytrium salamandrivorans sp. nov. causes lethal chytridiomycosis in amphibians. Proceedings of the National Academy of Sciences. 2013; 110:15325-15329.

Martin LB, Hopkins WA, Mydlarz LD, Rohr JR. The effects of anthropogenic global changes on immune functions and disease resistance. Pages 129-148 Year in Ecology and Conservation Biology 2010. 2010

McMahon TA, Boughton RK, Martin LB, Rohr JR. Exposure to the herbicide atrazine nonlinearly affects tadpole corticosterone levels. Journal of Herpetology. 2017; 52:270-273.

McMahon TA, Halstead NT, Johnson S, Raffel TR, Romansic JM, Crumrine PW, Boughton RK, Martin LB, Rohr JR. The fungicide chlorothalonil is nonlinearly associated with corticosterone levels, immunity, and mortality in amphibians. Environmental Health Perspectives. 2011; 119:1098-1103. [PubMed: 21463979]

McMahon TA, Halstead NT, Johnson S, Raffel TR, Romansic JM, Crumrine PW, Rohr JR. Fungicideinduced declines of freshwater biodiversity modify ecosystem functions and services. Ecology Letters. 2012; 15:714-722. [PubMed: 22587750]

McMahon TA, Rohr JR. Transition of chytrid fungus infection from mouthparts to hind limbs during amphibian metamorphosis. EcoHealth. 2015; 12:188-193. [PubMed: 25384612]

McMahon TA, Romansic JM, Rohr JR. Nonmonotonic and monotonic effects of pesticides on the pathogenic fungus Batrachochytrium dendrobatidis in culture and on tadpoles. Environmental Science \& Technology. 2013; 47:7958-7964. [PubMed: 23777241]

McMahon TA, Sears BF, Venesky MD, Bessler SM, Brown JM, Deutsch K, Halstead NT, Lentz G, Tenouri N, Young S, Civitello DJ, Ortega N, Fites JS, Reinert LK, Rollins-Smith LA, Raffel TR, Rohr JR. Amphibians acquire resistance to live and dead fungus overcoming fungal immunosuppression. Nature. 2014; 511:224-227. [PubMed: 25008531]

Nagelkerke NJ. A note on a general definition of the coefficient of determination. Biometrika. 1991; 78:691-692.

Pimentel D, Hurd LE, Bellotti AC, Forster MJ, Oka IN, Sholes OD, Whitman RJ. Food production and energy crisis. Science. 1973; 182:443-449. [PubMed: 17832454]

R Core Team. R: A language and environment for statistical computing. R Foundation for Statistical Computing; Vienna, Austria: 2013. URL http://www.R-project.org/

Relyea R, Hoverman J. Assessing the ecology in ecotoxicology: a review and synthesis in freshwater systems. Ecology Letters. 2006; 9:1157-1171. [PubMed: 16972879]

Relyea RA. The impact of insecticides and herbicides on the biodiversity and productivity of aquatic communities. Ecological Applications. 2005; 15:618-627.

Rohr JR, Civitello DJ, Crumrine PW, Halstead NT, Miller AD, Schotthoefer AM, Stenoien C, Johnson LB, Beasley VR. Predator diversity, intraguild predation, and indirect effects drive parasite transmission. Proceedings of the National Academy of Sciences of the United States of America. 2015; 112:3008-3013. [PubMed: 25713379]

Rohr JR, Crumrine PW. Effects of an herbicide and an insecticide on pond community structure and processes. Ecological Applications. 2005; 15:1135-1147. 
Rohr JR, Kerby JL, Sih A. Community ecology as a framework for predicting contaminant effects. Trends in Ecology \& Evolution. 2006a; 21:606-613. [PubMed: 16843566]

Rohr JR, McCoy KA. A qualitative meta-analysis reveals consistent effects of atrazine on freshwater fish and amphibians. Environmental Health Perspectives. 2010; 18:20-32.

Rohr JR, Palmer BD. Aquatic herbicide exposure increases salamander desiccation risk eight months later in a terrestrial environment. Environmental Toxicology and Chemistry. 2005; 24:1253-1258. [PubMed: 16111008]

Rohr JR, Palmer BD. Climate change, multiple stressors, and the decline of ectotherms. Conservation Biology. 2013; 27:741-751. [PubMed: 23773091]

Rohr JR, Raffel TR, Halstead NT, McMahon TA, Johnson SA, Boughton RK, Martin LB. Early-life exposure to a herbicide has enduring effects on pathogen-induced mortality. Proceedings of the Royal Society B-Biological Sciences. 2013; 280:20131502.

Rohr JR, Raffel TR, Sessions SK, Hudson PJ. Understanding the net effects of pesticides on amphibian trematode infections. Ecological Applications. 2008a; 18:1743-1753. [PubMed: 18839768]

Rohr JR, Sager T, Sesterhenn TM, Palmer BD. Exposure, postexposure, and density-mediated effects of atrazine on amphibians: Breaking down net effects into their parts. Environmental Health Perspectives. 2006b; 114:46-50. [PubMed: 16393657]

Rohr JR, Schotthoefer AM, Raffel TR, Carrick HJ, Halstead N, Hoverman JT, Johnson CM, Johnson LB, Lieske C, Piwoni MD, Schoff PK, Beasley VR. Agrochemicals increase trematode infections in a declining amphibian species. Nature. 2008b; 455:1235-1239. [PubMed: 18972018]

Rosenzweig, Ml. Paradox of enrichment: Destabilization of exploitation ecosystems in ecological time. Science. 1971; 171:385-387. [PubMed: 5538935]

Smalling KL, Reeves R, Muths E, Vandever M, Battaglin WA, Hladik ML, Pierce CL. Pesticide concentrations in frog tissue and wetland habitats in a landscape dominated by agriculture. Science of the Total Environment. 2015; 502:80-90. [PubMed: 25244036]

Staley ZR, Rohr JR, Senkbeil JK, Harwood VJ. Agrochemicals indirectly increase survival of E. coli O157:H7 and indicator bacteria by reducing ecosystem services. Ecological Applications. 2014; 24:1945-1953.

Voccia I, Blakley B, Brousseau P, Fournier M. Immunotoxicity of pesticides: a review. Toxicology and Industrial Health. 1999; 15:119-132. [PubMed: 10188195]

Voyles J, Young S, Berger L, Campbell C, Voyles WF, Dinudom A, Cook D, Webb R, Alford RA, Skerratt LF, Speare R. Pathogenesis of chytridiomycosis, a cause of catastrophic amphibian declines. Science. 2009; 326:582-585. [PubMed: 19900897]

Warnecke L, Turner JM, Bollinger TK, Lorch JM, Misra V, Cryan PM, Wibbelt G, Blehert DS, Willis CKR. Inoculation of bats with European Geomyces destructans supports the novel pathogen hypothesis for the origin of white-nose syndrome. Proceedings of the National Academy of Sciences of the United States of America. 2012; 109:6999-7003. [PubMed: 22493237]

Woodhams DC, Bosch J, Briggs CJ, Cashins S, Davis LR, Lauer A, Muths E, Puschendorf R, Schmidt BR, Sheafor B, Voyles J. Mitigating amphibian disease: strategies to maintain wild populations and control chytridiomycosis. Frontiers in Zoology. 2011; 8

Woodhams DC, Geiger CC, Reinert LK, Rollins-Smith LA, Lam B, Harris RN, Briggs CJ, Vredenburg VT, Voyles J. Treatment of amphibians infected with chytrid fungus: learning from failed trials with itraconazole, antimicrobial peptides, bacteria, and heat therapy. Diseases of Aquatic Organisms. 2012; 98:11-25. [PubMed: 22422126]

Young S, Nayak B, Sun S, Badgley BD, Rohr JR, Harwood VJ. Vancomycin-resistant enterococci and bacterial community structure following a sewage spill into an aquatic environment. Applied and Environmental Microbiology. 2016; 82:5653-5660. [PubMed: 27422829] 

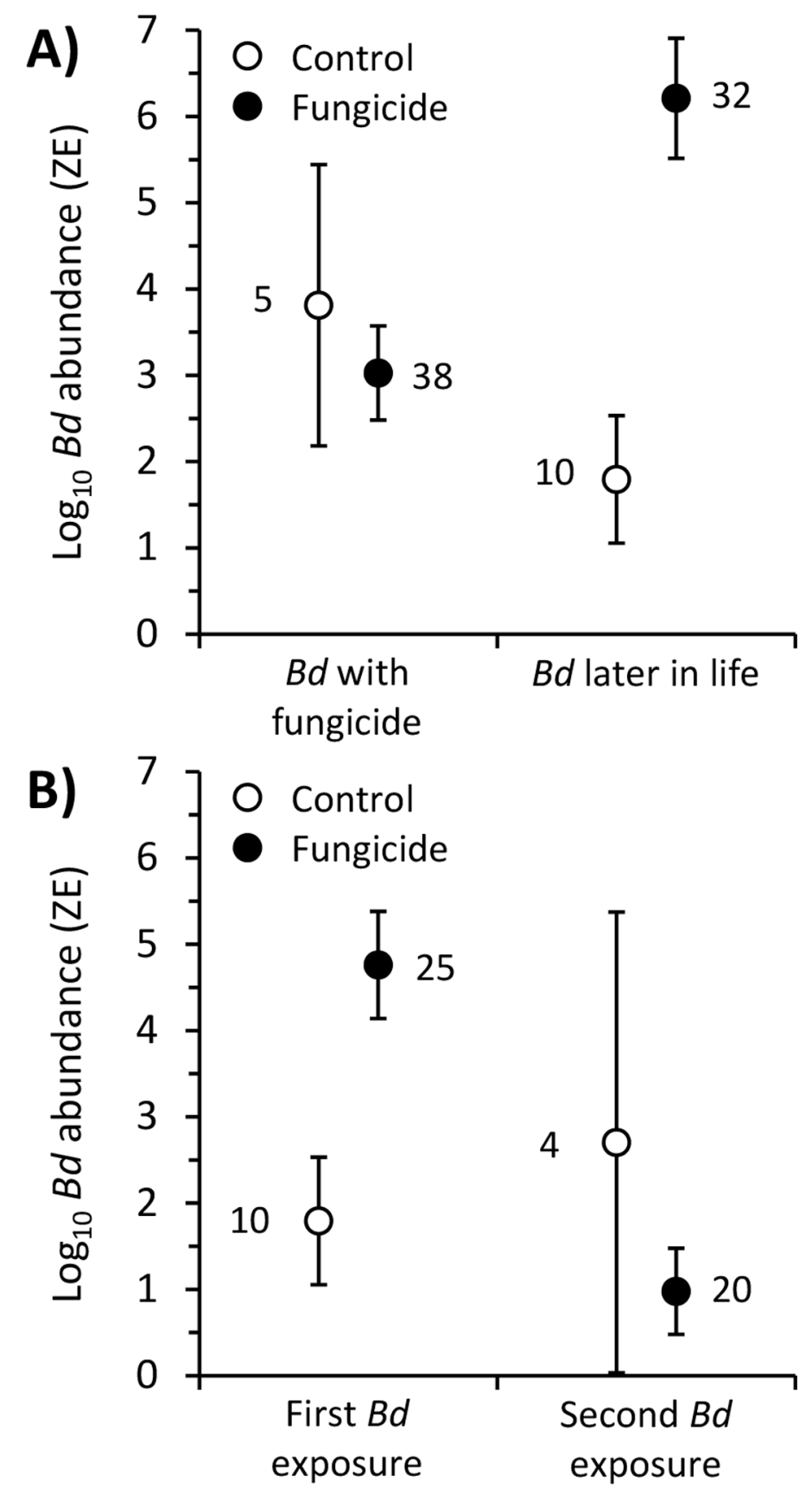

Fig. 1.

Effects of fungicide treatments on mean $( \pm 1 \mathrm{SE}) \log _{10}$ Batrachochytrium dendrobatidis $(B d)$ abundance on Cuban tree frogs $\mathbf{A}$ ) exposed to $B d$ for the first time as tadpoles simultaneous with the fungicide treatments versus for the first time as post-metamorphic frogs, 71 days after the previous exposure to fungicide treatments (Fungicide $\times$ timing of $B d$ exposure: $X^{2}=25.98, p<0.001$ ), and B) exposed to $B d$ for the first versus second time as a post-metamorphic frog (Fungicide $\times$ number of $B d$ exposures: $X^{2}=15.47, p<0.001$ ). There were no statistically significant differences among the three tested fungicides (azoxystrobin, chlorothalonil, mancozeb) and thus they were pooled for subsequent analyses to increase 
statistical power and facilitate visualization. Numbers next to data points are associated sample sizes (which vary because of mortality and re-assignment of frogs to appropriate treatments if they died before receiving their assigned $B d$ exposure; see text for details). 

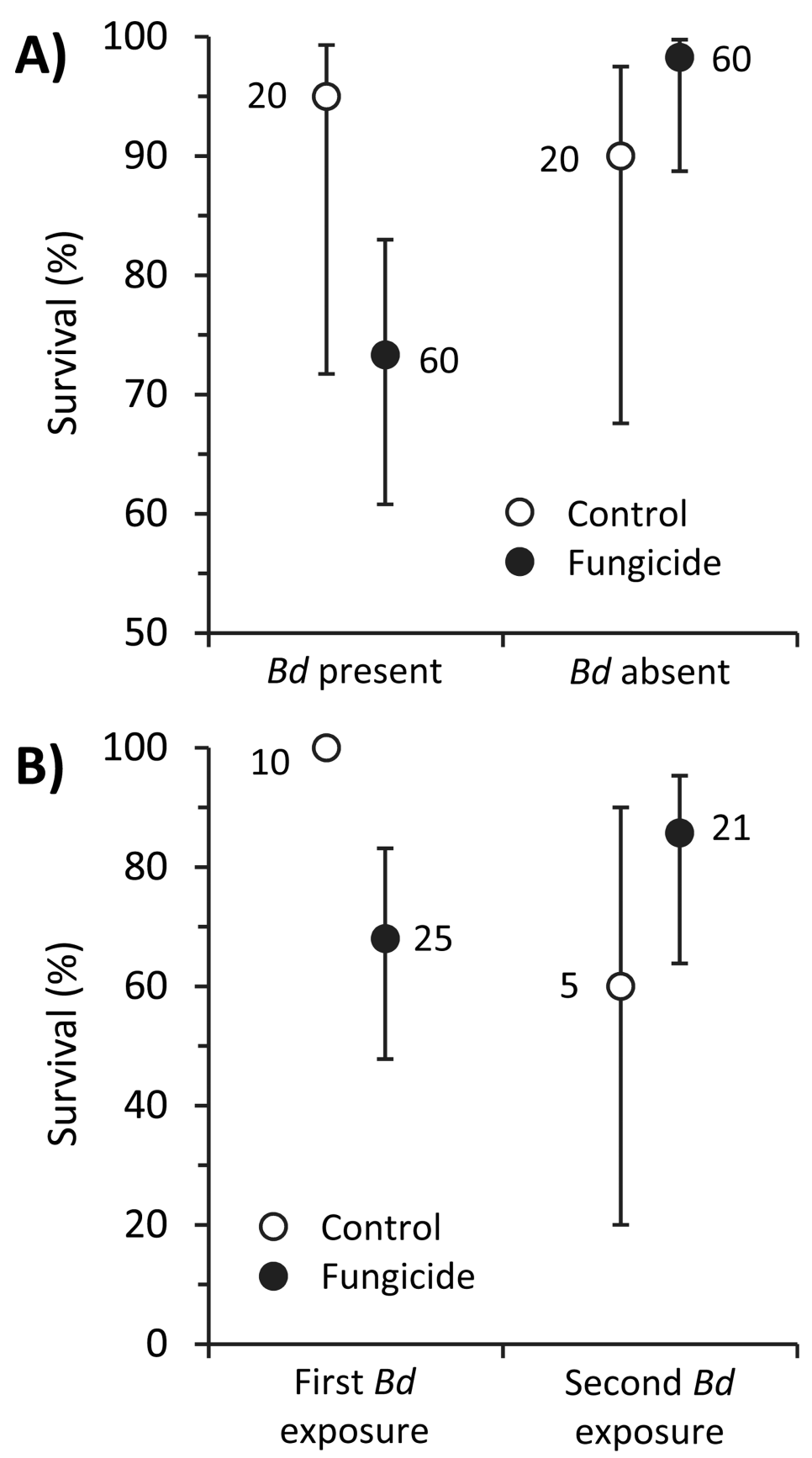

Fig. 2.

Mean ( $\pm 95 \%$ CI) survival of Cuban tree frogs exposed A) to fungicide and Batrachochytrium dendrobatidis $(B d)$ treatments simultaneously as tadpoles (Fungicide $\times$ $B d$ : $X^{2}=6.47, P=0.011$ ) or $\mathbf{B}$ ) to fungicides treatments as tadpoles and then to $B d$ for the first or second time as a post-metamorphic frog (a mean of 71 days after their last exposure to fungicide; Fungicide $\times$ number of $B d$ exposures: $\left.X^{2}=6.89, P=0.009\right)$. There were no statistically significant differences among the three tested fungicides (azoxystrobin, chlorothalonil, mancozeb) and thus they were pooled for subsequent analyses to increase statistical power and facilitate visualization. Numbers next to data points are associated 
sample sizes (which vary because of mortality and re-assignment of frogs to appropriate treatments if they died before receiving their assigned $B d$ exposure; see text for details). 


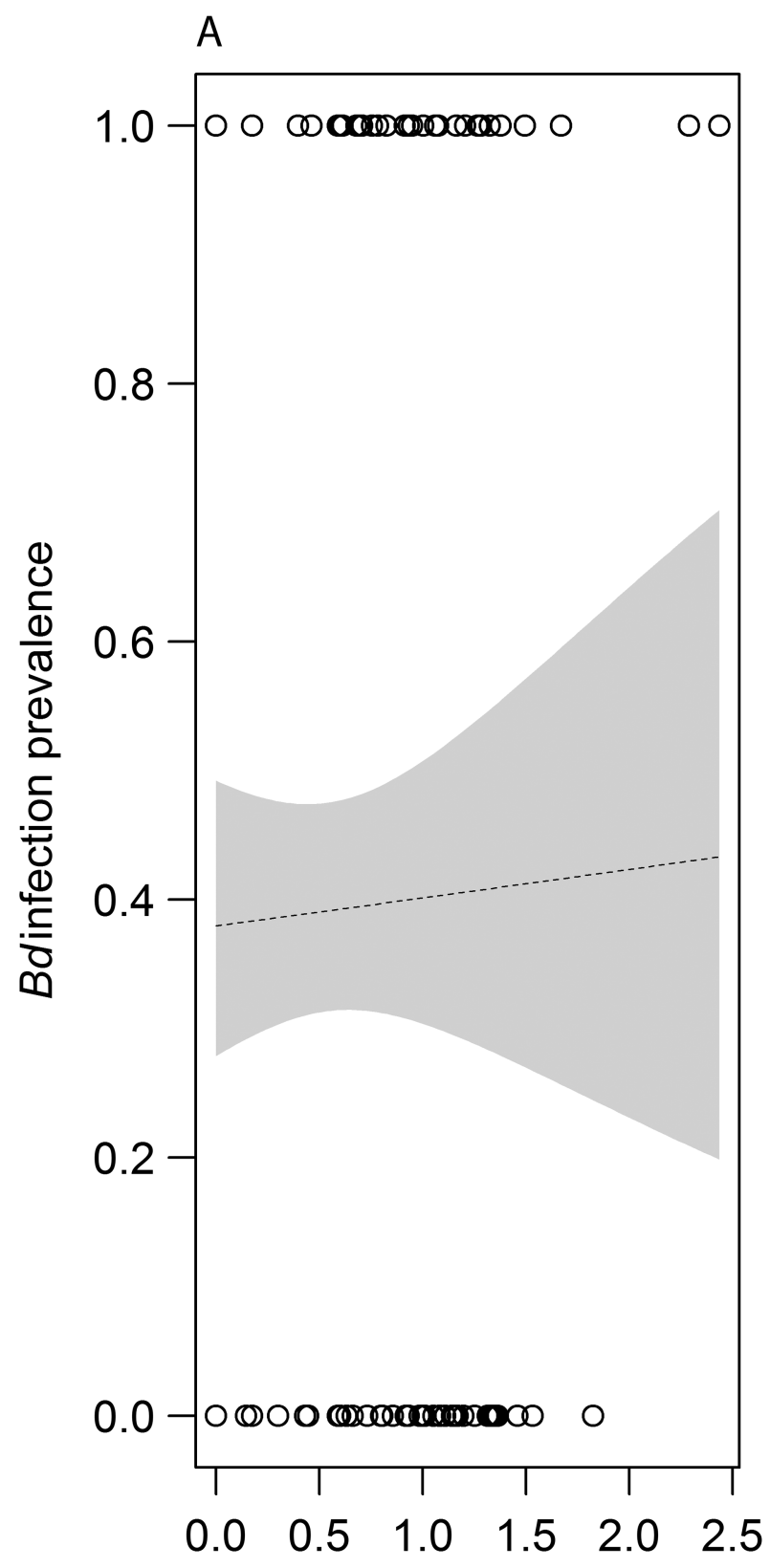

Fungicides in frog tissue

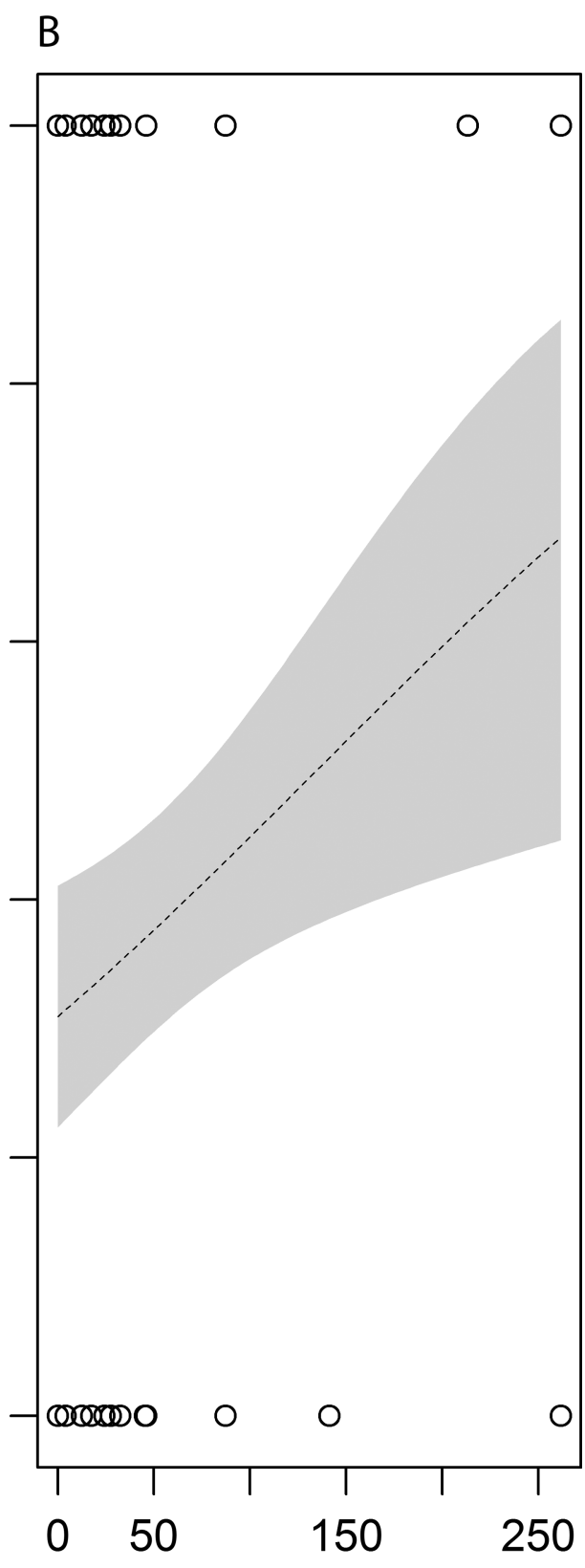

Fungicides in wetland

Fig. 3.

Relationship between the prevalence of Batrachochytrium dendrobatidis $(B d)$ infections of 138 frogs and the concentration of fungicides in frog tissues $\left(\log _{10}(\mu \mathrm{g} / \mathrm{kg}+1)\right.$-transformed, $X^{2}=0.03, p=0.858, \mathbf{A}$ ) and in wetlands (sediment $[\mu \mathrm{g} / \mathrm{kg}]$ plus water $[\mu \mathrm{g} / \mathrm{L}], X^{2}=7.10$, $p=0.008, \mathbf{B})$. Shown are logistic regression plots and associated $95 \%$ confidence bands (shaded). 


\section{Table 1}

Effects of various concentrations of the fungicides azoxystrobin, chlorothalonil, and mancozeb on the abundance on Batrachochytrium dendrobatidis zoospores cultured in welled plates.

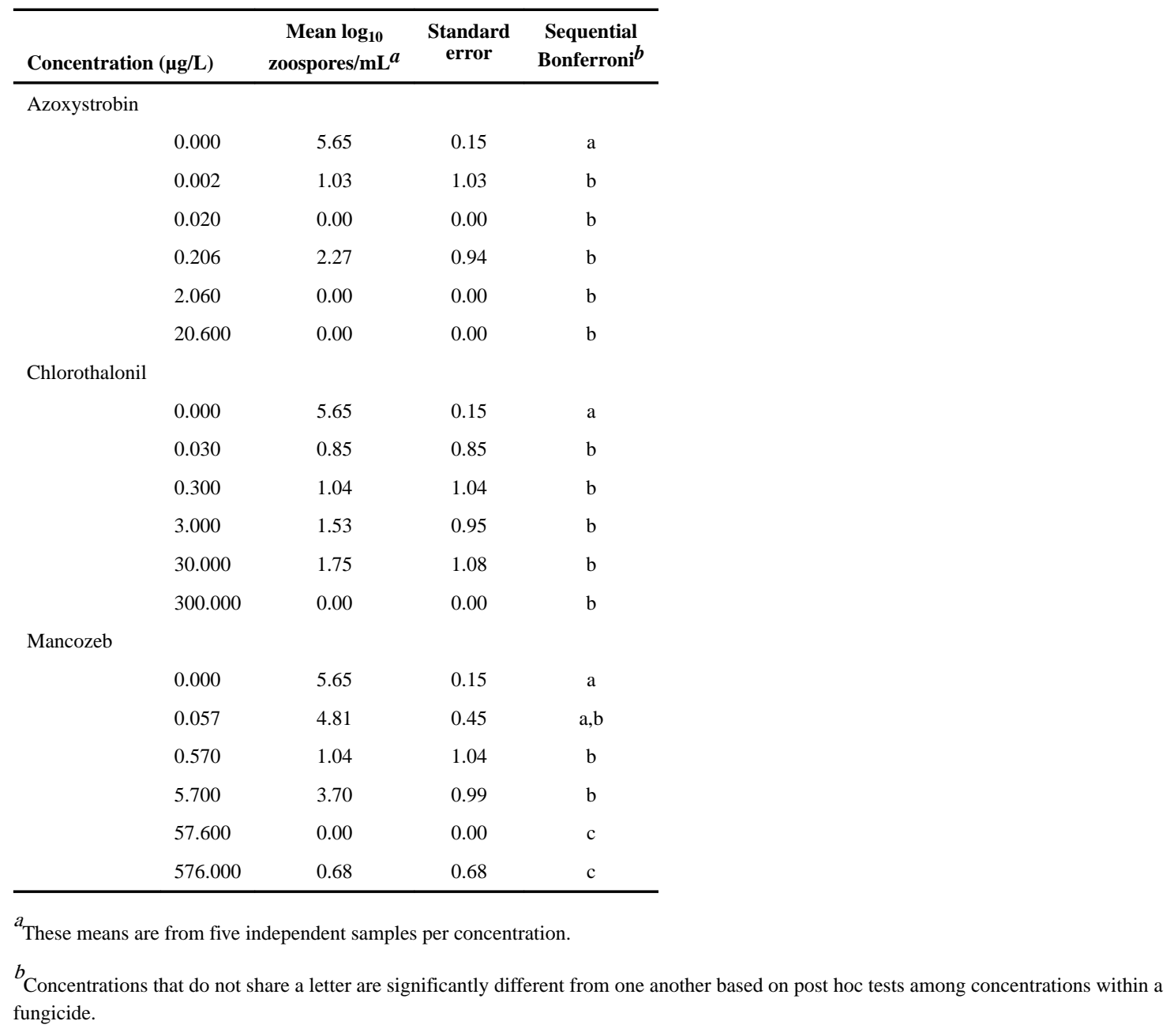

